\title{
Have workplace forums contributed to worker participation? Some management perceptions
}

\author{
R. van der Walt* \\ Department of Human Resources Management, University of Pretoria, \\ Pretoria 0002, Republic of South Africa \\ ruan.vanderwalt@up.ac.za
}

Received March 2008

\begin{abstract}
The Labour Relations Act No. 66 of 1995 introduced workplace forums (WPFs) as a structure to promote employee participation in decision-making in the workplace. The study gathered the perceptions of management representatives regarding the reason(s) for the establishment, the process of establishment as well as the functioning of workplace forums in their respective organisations. The results indicate that contrary to popular belief management representatives understand that greater employee participation is the reason for the establishment of a workplace forum and that the establishment and functioning of workplace forums take place in accordance with the prescriptions of the Act. It is recommended that management create a climate in which more workplace forums can be established.
\end{abstract}

*To whom all correspondence should be addressed.

\section{Introduction}

The relationship between employers and the representatives of employees in South Africa during most of the $20^{\text {th }}$ Century has been characterised by conflict and hostility between the parties (Finnemore, 2002: 19-29). It was clear to the new government that urgent attention had to be given to labour relations in order to rebuild the country's economy and introduce industrial democracy. As early as July 1994, a ministerial task team was appointed to draft new legislation to revolutionise workplace relations (Finnemore, 2002: 2932).

As a liberation movement, the African National Congress (ANC) in the Reconstruction and Development programme (ANC, 1994) propagated democracy as one of its key values. This value has found its way into the Constitution of the Republic of South Africa (RSA, 1996) as a cornerstone value. The idea was that democratic values would be extended to spheres of the South African society, including the workplace. This was to be achieved by new legislation after the ANC came to power in 1994. One of the first acts passed by the new government was the Labour Relations Act No 66 of 1995 (the LRA) (RSA, 1995a).

The new LRA introduced the concept of workplace forums (WPFs). Du Toit, Woolfrey, Murphy, Godfrey, Bosch and Christie (1998: 45) remark that this represented a major shift from the traditional style of adversarial collective bargaining between employers and trade unions to a division of labour between trade union and workplace forums representing employee interests.

The reason for the separation of distributive bargaining and the cooperative relations can be found in the Explanatory
Memorandum to the Draft Bill (RSA, 1995b). Workplace forums would have statutory recognition to expand worker representation beyond the limits of collective bargaining by providing workers with an institutionalised voice in managerial decisions.

From the Explanatory Memorandum it is clear that the drafters of the LRA were strongly influenced by similar structures and practices in Western Europe (RSA, 1995b; Wood \& Mahabir, 2001). In the 1970s managements across Europe realised that if they were to move from mass production to flexible production they would have to give employees a say in decision-making. This led to the development of a system of employee participation which has taken the form of works councils in countries such as Sweden (Anstey, 1997), Germany (Sterner, 1996) and the Netherlands (Visser, 1995: 19-115). Workplace forums as provided for in the LRA are similar to these works councils.

The drafters of the LRA were very conscious of the need to improve the competitiveness of the South African industry. Godfrey and Du Toit (2000:15) have also noted the importance of WPFs for the process of enterprise restructuring to improve productivity and to become internationally competitive as envisaged in the Explanatory Memorandum. The drafters' position was that WPFs were not meant to replace collective bargaining but to supplement it through a system of participation dealing with non-wage issues. A clear distinction is made between workplace forums and collective bargaining with enterprise-level workplace forums placed in a position similar to the works councils in Germany. A further reason for the drafters to make this clear distinction was that trade unions had achieved considerable success with collective bargaining and would not have permitted a reduction of the influence 
they had gained through collective bargaining. Trade unions also had bad memories of works committees and works councils under the previous dispensation. This led to the term 'workplace forums' being preferred above 'works councils', as they are called in Germany.

In spite of the promise that WPFs seemed to hold for promoting worker participation and breaking with adversarial behaviour of the past (typified by disputes and strikes), only a limited number of WPFs have been established, as Nel and Kirsten (2000) and Wood and Mahabir (2001) have indicated. Should the number of functioning WPFs continue to remain limited, one of the objectives of the LRA, namely greater employee participation, will not be achieved. Neither will the objective of the drafter of the LRA, to improve the competitiveness of South African industries, be achieved. Okharedia (2007) highlighted the reasons for the establishment of WPFs, namely to encourage democracy in the workplace through employee participation and to promote efficiency in the production system.

At present there is a paucity of knowledge regarding WPFs in South Africa. This article hopes to shed some light on the subject.

The study on which the article is based investigated management representatives' perceptions of WPFs in five South African organisations, which are members of different industries. In particular, the reasons for establishing the WPFs, the process followed in establishing the WPFs, as well as the functioning of the WPFs in the organisations that participated in the study, were examined.

\section{Literature review}

As mentioned previously, many of the features of works councils as found in West European countries have been taken over for use in WPFs. Therefore one of the best known examples of the works council systems, namely that of Germany, will be used to draw parallels with WPFs in South Africa. Du Toit et al. (1998: 45) point out that despite any superficial resemblance between WPFs and work committees established in terms of the Black Labour Relations Act of 1953, or works councils in terms of section 34A of the LRA of 1956, on closer inspection neither of these amounts to a statutory system of worker participation as conceived in the LRA of 1995.

Worker representation in Germany can be traced back to 1835 when Robert von Mohl introduced a proposal for the establishment of workers' committees with the view of profit-sharing, a rather progressive idea at the time. During the period 1870 to 1890 some religious and liberal companies voluntarily introduced worker representation. Worker committees established during World War I necessitated by economic demand of the war effort ensured legal protection for the first time (Sterner, 1996:8).

Worker participation was derailed by the rise of the Third Reich in 1933. After the end of World War II a need was felt to restructure the entire German economy by drafting a new act on worker participation. The unions were in favour of co-determination in relevant economic matters, but the Works Council Act of 1952 only provided for consultation and excluded joint decision making. With the passing of the Works Constitution Act of 1972, works councils were afforded co-determination rights in the form of joint decision-making (Bendix, 1995; Sterner, 1996: 8-9).

The departure point of the study was the report of the Commission for Conciliation, Mediation and Arbitration (CCMA), which listed all WPFs registered at the time. The CCMA is the institution created by the LRA of 1995 inter alia to facilitate the establishment of WPFs. Workplace forums are the vehicle of choice to institutionalise industrial democracy in South African workplaces, with the advancement of industrial democracy, namely employee participation in decision-making, as one of the primary objectives of the LRA. In their study, Msweli-Mbanga and Potwana (2006) found that the more access employees have to participation, the less the resistance to change efforts in organisations.

In terms of Chapter $\mathrm{V}$ of the LRA, all trade union organisations that wish to establish a WPF have to apply to the CCMA. Unfortunately, not all applicants have thus far fulfilled all the statutory requirements for registration and consequently many have failed in establishing statutorily recognised WPFs. Wood and Mahabir (2001:241) have also pointed out the scarcity of workplace forums.

\section{General functions of a workplace forum}

Section 79 sets out four functions of workplace forums, the first two of which are general obligations owed by the WPF to employees and the employer and the other two are rights which the forum can claim from the employer (RSA, 1995a; Du Toit et al., 1998: 255). A workplace forum established in terms of Chapter V section 79 of the LRA:

(a) must seek to promote the interests of all employees in the workplace, whether or not they are trade union members;

(b) must seek to enhance efficiency in the workplace;

(c) is entitled to be consulted by the employer, with a view to reaching consensus, about matters referred to in section 84; and

(d) is entitled to participate in joint decision-making about the matters referred to in section 86 .

One of the main functions of a WPF is to promote the interests of all employees in the workplace, whether they are members of the trade union or not. Cheadle (1995:75) writes:

[I]t is for the above reason that the composition of the workplace forum must be by way of direct election of members by the employees in the workplace (section $82(1)(c)$ ). However, if a representative trade union is recognised by the employer for purposes of collective bargaining in respect of all employees in the workplace, then the trade union may choose the members of the 
workplace forum from among its elected representatives in that workplace.

Consequently, the composition of a WPF is very important, since its composition will possibly determine the ability of the forum to advance the interests of all employees in the workplace. As WPFs can only be initiated by trade unions, there is always the possibility of conflict between serving the interests of all employees in the WPF and serving only the interests of the union members. It is for this reason that section 78(b) specifies that the trade union(s) concerned must be a majority union or unions. This is to ensure that unions will have the ability to represent the democratic views in that workplace. Section 94 provides for an aggrieved employee, other employees, registered trade unions, a representative trade union or even an employer to hold the WPF accountable by challenging the validity of an agreement.

A second function of a WPF is to advance efficiency in the workplace. Efficiency in the workplace has not been defined in the LRA and it still has to be seen how it is going to be defined. Some indication of what efficiency might constitute is given by Du Toit (1995: 792):

The only imperative identified with the functions of workplace forums is that of seeking to enhance efficiency in the workplace. Such an explicit directive will be binding on a court in a way that a general statement of intent by the Minister is not. The implication is that economic efficiency must take precedence over the requirements of democracy and that if 'efficiency' as understood by the courts demands it, workers' rights to be involved in decision-making must be curtailed.

Although WPFs are intended to enhance cooperative behaviour in the workplace as is seen from the function mentioned above, there is always the possibility of conflict between management and the WPF arising from the same matters that are discussed by management and the union.

\section{Launching a workplace forum}

In terms of section $80(1)$ and (2) of the LRA, any representative union may apply for the establishment of a WPF in a workplace employing more than 100 employees. The LRA specifies that application should be made to the Commission for Conciliation, Mediation and Arbitration (CCMA) and that a copy of the application be sent to the employer (Grogan, 1998: 212).

From reading section 78 (b) it is clear that to be a representative union, a union or unions acting jointly must represent the majority of employees. In the opinion of Du Toit et al. (1998: 259) this leaves minority unions with three options, namely 1) to increase their membership to meet the cut-off point; 2) that minority unions may form a jointventure for the purpose of gaining a majority; or 3) that the minority union(s) can establish a non-statutory structure with the view to consultation and joint decision-making with the employer.

A WPF may only be established in an organisation that employs 100 or more employees. Both Bosch and Du Toit, cited in Benjamin and Cooper (1995: 266), and Olivier (1996: 808) believe this threshold is far too high and could exclude $74 \%$ of employees in the formal sector. This begs the question: How many organisations will be able to meet these requirements? Van der Walt $(1997 ; 1998)$ also found that the prescribed number requirement excludes many organisations. Nel and Kirsten (2000: 53) suggest that it should be made possible to launch WPFs in organisations with fewer than 100 employees to overcome this problem.

Cheadle, as one of the LRA drafters (Benjamin \& Cooper, 1995: 267), states that the threshold was determined because larger workplaces are more likely to possess the necessary skill and knowledge to make WPFs function effectively. This argument is unconvincing since it does not have the evidence to substantiate such a claim. An obvious way to overcome this problem would be to require employers to ensure that members of their WPF and the relevant managers undergo appropriate high-quality training. This could be viewed as an extension of the philosophy that requires employers to make greater efforts to train and develop their employees as envisaged in the Skills Development Act No. 97 of 1998 and the Skills Development Levies Act No. 9 of 1999.

In spite of the requirements of the LRA, smaller enterprises are free to establish their own participating structures. However, consideration should be given to reducing the prescribed threshold in South Africa to a number more in line with international practice.

\section{Perceived defects in the workplace forum system}

Although the Act is intended to promote employee participation through WPFs, this objective is severely threatened by the dominant role given to trade unions. The fact that a collective agreement is to be concluded for the establishment of a WPF introduces the concept of collective bargaining and adversarialism. The Act further makes it possible for the election to the WPF of trade union shop stewards who may have a mind-set of adversarial bargaining which is contradictory to the cooperative approach necessary for employee participation. The principle that the WPF must serve the needs of all the employees is also threatened as most members will come from a trade union (Olivier, 1996: 809). Khoza (1999: 139) believes that although the Act provides for forums separate from the collective bargaining structures, the Act does not succeed in this institutional separation. At best the forums will be supplementary structures for collective bargaining dominated by unions.

In Germany, works councils exist independently of trade unions. The Works Constitution Act prescribes the separation of functions and personnel and functional links between trade unions and works councils. Non-unionised employees are permitted to initiate works councils so that they will have only functional and personnel links with the trade unions (Halbach, 1994: 134).

In South Africa, trade unions and WPFs are intended to be independent institutions but they are linked by some 
personnel and functional links. The fact that trade unions presently enjoy significant power over WPFs creates doubts about the true independence of the WPF. Real independence is necessary in order to promote employee participation for the benefit of all employees in the workplace.

\section{Requirements for the constitution of WPFs}

Guidelines with regard to the requirements that must be met in the constitution to be drawn up for a WPF are contained in Section 82 and Schedule 2 of the LRA. The constitution of every WPF must include a formula for determining the number of seats in the WPF.

One of the requirements is that the constitution must establish a formula for the distribution of seats to reflect the occupational structures of the workplace, provide for direct election of members of the WPF by employees, and provide for the appointment of an employee as election officer as prescribed in Section 82.

The constitution may establish a procedure for conciliation and arbitration of proposals in respect of which the employer and the WPF do not reach consensus, establish a coordinating WPF to perform any of the general functions of a WPF and one or more subsidiary WPFs to perform any specific functions of a WPF, and include provisions that depart from section 83 to section 92. The constitution of a WPF in this sense also binds the employer, therefore it is important to know what the employers' and managements' perceptions of WPFs are.

\section{Methodology}

As part of a qualitative study questions were included to assess what impact WPFs have made in the participating organisations. The scope of the study was limited due to the small number of organisations that had functioning WPFs. It appears that trade unions are reluctant to apply to the CCMA for the establishment of WPFs mainly for fear that their standing in the relevant organisation would be adversely affected. Five organisations, from various sectors of the economy, agreed to participate in the study. They were handled as separate cases.

The method utilised in this study was Miles and Huberman's (1984; 1994) approach to qualitative analysis. This approach views data analysis as concurrent flows of activity: data collection, data reduction, data display and conclusion drawing/verification. As a result of the interactive nature of the model, data reduction and data display could take place concurrently.

An extensive literature review was undertaken in order to obtain background information for execution of the research. The second source for data collection was the five organisations that had agreed to participate in the study. They were handled as separate cases and came from various sectors of the economy, namely agricultural research (Case A), tertiary education (Case B), research and development (Case C), the private hospital (Case D) and armaments manufacturing (Case E).
A number of data collection methods were employed, namely a literature study, a survey questionnaire and indepth interviews within the qualitative research tradition. Questions relevant to WPFs were included in the questionnaire.

To meet one of the criteria of good qualitative research, namely credibility, triangulation of multiple sources of data was applied as suggested by Lincoln and Guba (1985: 20). Each organisation that participated in the study was requested to have two questionnaires completed, one by management representatives and an identical one by worker representatives. The management respondents were requested to give the view of management and the shop stewards/worker representatives the views of the workers in their respective organisations. In other words, multiple views were obtained in each case as well as across different cases in various sectors of the economy.

Where possible, available agendas, minutes of meetings and any other documents related to interaction between management and workers were obtained. Further data for analysis was obtained from in-depth interviews with respondents when it was necessary to get more clarity on certain responses.

For purposes of this study, Gauteng Province was chosen as the setting of the investigation as it is the province with the greatest economic activity. In the CCMA report available at the time, 17 cases were registered for Gauteng Province. One of the cases registered had incomplete contact details which rendered that particular case unusable for research purposes. The remaining organisations were approached to participate in the study and cooperation was obtained from seven of them.

In the study the data from the questionnaires was reduced through the following steps: The data from each questionnaire was captured and summarised to build one worksheet with responses of the management and the trade union/worker representatives for each organisation. Relevant additional information from agendas, minutes of meetings, memoranda, etc. were also recorded on the worksheets. From the worksheets the data was transferred to displays such as the various tables and lists used in the study.

\section{Analysis and results}

Once the questionnaires had been completed and the relevant documents had been received, the responses of the management representatives were summarised and tabulated. In a number of cases it was necessary to conduct follow-up semi-structured interviews to clarify certain responses. The responses to each of the survey questions and sub-questions on the selected aspects of WPFs were recorded and tabulated prior to analysis.

The responses of management representatives of organisations (Cases A, B, C, D and E) with WPFs are indicated in Table 1. 
Table 1: Compilation of responses of management representatives of organisations with WPFs

\begin{tabular}{|c|c|c|c|c|c|}
\hline & A & B & $\mathbf{C}$ & $\mathbf{D}$ & $\mathbf{E}$ \\
\hline $\begin{array}{l}\text { 1. Reasons for } \\
\text { establishment }\end{array}$ & $\begin{array}{l}\text { Effective } \\
\text { communication } \\
\text { between } \\
\text { management and } \\
\text { workers }\end{array}$ & $\begin{array}{l}\text { Promote worker } \\
\text { participation and } \\
\text { reach more employees }\end{array}$ & $\begin{array}{l}\text { Promote interests of } \\
\text { all workers to } \\
\text { enhance efficiency in } \\
\text { workplace }\end{array}$ & $\begin{array}{l}\text { To promote worker } \\
\text { participation }\end{array}$ & $\begin{array}{l}\text { Have a Joint } \\
\text { Consultative Forum } \\
\text { and } \\
\text { other non- aligned } \\
\text { structures }\end{array}$ \\
\hline $\begin{array}{l}\text { 2.Process drawing } \\
\text { up constitution }\end{array}$ & $\begin{array}{l}\text { Requirements of } \\
\text { section } 82 \text { of LRA }\end{array}$ & $\begin{array}{l}\text { Prescribed procedures } \\
\text { and help from CCMA } \\
\text { after referral }\end{array}$ & CCMA & None & $\begin{array}{l}\text { Election in different } \\
\text { constituencies Elected } \\
\text { members' input into } \\
\text { constitution }\end{array}$ \\
\hline $\begin{array}{l}\text { 3. What external } \\
\text { help received }\end{array}$ & CCMA & CCMA & CCMA & None & Internal resources \\
\hline $\begin{array}{l}\text { 4. Number of } \\
\text { WPF members }\end{array}$ & 12 & 20 & 14 & 12 & 16 \\
\hline $\begin{array}{l}\text { 5. Election } \\
\text { process of WPF } \\
\text { members }\end{array}$ & $\begin{array}{l}\text { CCMA set election } \\
\text { date }\end{array}$ & $\begin{array}{l}\text { Constituencies, } \\
\text { nominations and } \\
\text { election into LRA }\end{array}$ & $\begin{array}{l}\text { Trade Unions elected } \\
\text { their representatives } \\
\text { with alternates for } \\
\text { each member }\end{array}$ & $\begin{array}{l}\text { Management not } \\
\text { involved but } \\
\text { elections were held }\end{array}$ & $\begin{array}{l}\text { Election in different } \\
\text { constituencies Elected } \\
\text { members' input into } \\
\text { constitution }\end{array}$ \\
\hline $\begin{array}{l}\text { 6. How often does } \\
\text { WPF meet? }\end{array}$ & $\begin{array}{l}\text { Every second } \\
\text { month }\end{array}$ & Monthly & Once a month & Monthly & $\begin{array}{l}\text { At first monthly; now } \\
\text { quarterly }\end{array}$ \\
\hline $\begin{array}{l}\text { 7. What is } \\
\text { discussed? }\end{array}$ & $\begin{array}{l}\text { Performance } \\
\text { management }\end{array}$ & $\begin{array}{l}\text { Smoking policy, code } \\
\text { of conduct, } \\
\text { disciplinary } \\
\text { code/procedure, } \\
\text { restructuring }\end{array}$ & $\begin{array}{l}\text { Disciplinary } \\
\text { code/procedure, } \\
\text { smoking policy, } \\
\text { employment equity }\end{array}$ & $\begin{array}{l}\text { Employment } \\
\text { equity, } \\
\text { remuneration, } \\
\text { smoking policy, } \\
\text { disciplinary process }\end{array}$ & $\begin{array}{l}\text { Employment equity, } \\
\text { appointments, } \\
\text { budgets, information } \\
\text { processes }\end{array}$ \\
\hline $\begin{array}{l}\text { 8. How often does } \\
\text { WPF meet with } \\
\text { employees? }\end{array}$ & $\begin{array}{l}\text { Every second } \\
\text { month }\end{array}$ & Once a quarter & Four times per annum & Every three months & Monthly or by need \\
\hline $\begin{array}{l}\text { 9. WPF } \\
\text { opportunity to } \\
\text { make } \\
\text { representation? }\end{array}$ & $\begin{array}{l}\text { Yes } \\
\text { Smoking policy }\end{array}$ & $\begin{array}{l}\text { Yes } \\
\text { Smoking policy, code } \\
\text { of conduct, } \\
\text { disciplinary } \\
\text { code/procedure, } \\
\text { restructuring }\end{array}$ & Yes, if they so wish & $\begin{array}{l}\text { Yes, WPF is free to } \\
\text { do so }\end{array}$ & $\begin{array}{l}\text { Yes, during } \\
\text { restructuring the } \\
\text { organisation, with } \\
\text { telephone policy and } \\
\text { recognition award } \\
\text { policy }\end{array}$ \\
\hline
\end{tabular}

Further analysis of the questions relating to WPFs gave the following results:

The management representatives' responses show that three of the five cases listed the promotion of worker participation as the reason for the establishment of the WPF in their organisations.

In describing the process followed during the drawing up of the constitution of the WPFs, all the management representatives of the participating organisations reported that they had followed the requirements for constitutions as prescribed in section 82 of the LRA of 1995. Only one case reported that they had requested assistance from the CCMA with the drawing up of a constitution.

Regarding to the use of external resources in drawing up the constitutions of their WPFs, three of the management representatives indicated that they had used the CCMA. The other two management representative indicated that their organisations only made use of internal resources.

Management representatives reported that the number of WPF members in their organisations ranged between 12 and 20 members. It must be pointed out that the LRA provides for a maximum of 20 members. WPF members were generally elected after nominations had been called for and the election dates determined. One respondent confused the role of the CCMA and that of the election officer, as the latter determines the election date.

The responses of the management representatives indicate that WPF members were generally elected after nominations had been called for and the election dates determined.

Three of the five management representatives indicated that their WPFs meet monthly. One organisation reported that their WPF meets every second month. Case $C$ reported that their WPF meets four times a year. Case $\mathrm{E}$ indicated that their WPF equivalent structure initially met every month, but that this arrangement has since changed to meeting once a quarter according to their needs.

Three topics were indicated by at least three of the management representatives. Of these, disciplinary codes and procedures were indicated by three of the five cases. This is in fact one of the topics on which an employer must consult and reach consensus with a WPF in the absence of a collective agreement regulating matters for joint decisionmaking in terms of section 86(1) of the LRA. 
Regarding the meeting of the WPF with employees, one of the management representatives indicated a monthly meeting and another bi-monthly meetings. Three of the management respondents indicated quarterly meetings.

All the worker representatives indicated that the respective WPFs were given the opportunity to make representations to the management of the particular organisation, with some indicating specific examples of matters raised by the WPF.

\section{Conclusions}

From the responses of the management representatives it appears that they understand the reason for the establishment of WPFs, namely to increase employee participation, which is also one of the objectives of the LRA. The other responses of management seem to indicate that as far as they were aware their respective WPFs followed the prescriptions of the LRA in terms of drawing up the constitution for the WPFs, calling for external help, the number of members and the election of members. The other responses had to do with the actual functioning of WPFs, such as the frequency of meeting, topics discussed and the frequency of the WPFs meeting with all employees. The remaining response referred to the WPFs being afforded the opportunity to make representation to managements and which were generally satisfactory from a management perspective.

It is recommended that managements do much more to create a climate in which WPFs could be established and thrive. If managements fail to do so, two of the objectives of the LRA, namely efficiency in the workplace - such as productivity and competitiveness - and employee participation in decision-making, will not be achieved. More research into WPFs in other provinces and industries should also be undertaken to increase the knowledge and insight into these participative structures.

Participation between employers and employees and their representatives is much better than energy- and timeconsuming adversarial behaviour. Employers should be encouraged to support participation in decision making with employees and so move towards the ideal of industrial democracy in South African workplaces.

\section{References}

African National Congress. 1994. The Reconstruction and Development Programme. Braamfontein: Umanyano.

Anstey, M. 1997. 'Corporatism, collective bargaining and enterprise participation: A comparative analysis of the change in South African labour system'. Unpublished doctoral thesis, University of Port Elizabeth, Port Elizabeth.

Bendix , W. 1995. 'Workplace Forums: Shadows of a shady past or beacons for reform', Industrial Relations Journal of South Africa, 15(3):25-37.

Benjamin, P. \& Cooper, S. 1995. 'Innovation and continuity: Responding to the Labour Relations Bill', Industrial Law Journal. 16(1):258-277.
Cheadle, H. 1995. Current labour law. Cape Town: Juta and Co.

Du Toit, D. 1995. 'Corparatism and collective bargaining in a democratic South Africa', Industurial Law Journal, 16(4): 785-805.

Du Toit, D., Woolfrey, D., Murphy, J., Godfrey, S., Bosch, D. \& Christie, S. 1998. The Labour Relations Act of 1995. $2^{\text {nd }}$ Edition. Durban: Butterworths.

Godfrey, S. \& Du Toit, D. 2000. 'Workplace Forums proposals: Opportunity or threat?' South African Labour Bulletin, 24(6):13-15.

Finnemore. M. 2002. Introduction to labour relations in South Africa. $8^{\text {th }}$ Edition. Durban: Butterworths.

Grogan, J. 1998. Workplace law. $3^{\text {rd }}$ Edition. Cape Town: Juta and Company.

Halbach, G. 1994. Labour law in Germany: An overview. $5^{\text {th }}$ Edition. Federal Ministry of Labour and Social Office, Germany.

Khoza, F. J. 1999. 'An examination of employee participation as provided for in the Labour Relations Act 66 of 1995'. Unpublished masters thesis. Grahamstown: Rhodes University.

Lincoln, Y. \& Guba, E. 1985. Naturalistic inquiry. Beverly Hills, CA: Sage Publications.

Msweli-Mbanga, P. \& Potwana, N. 2006. 'Modelling participation, resistance to change and organisational citizenship behaviour: A South African case', South African Journal of Business Management, 37(1):21-29.

Miles , M. B. \& Huberman, A. M. 1984. Qualitative data analysis: A source book of new methods. London: Sage Publications.

Miles , M. B. \& Huberman, A. M. 1994. Qualitative data analysis: A source book of new methods. London: Sage Publications.

Nel, P. S. \& Kirsten, M. 2000. 'Workplace Forums and worker participation in South Africa: Some research results', South African Journal of Labour Relations, Autumn/Winter: 28-55.

Okharedia , A. A. 2007. 'Workplace Forums - boon or bane of South African industry?' Convergence, 8(1):86-89.

Olivier, M. P. 1996. 'Workplace Forums: Critical questions from a labour law perspective', Industrial Law Journal, 17(5):803 -814.

RSA (Republic of South Africa). 1995a. Labour Relations Act No 66 of 1995. Pretoria: Government Printers. 
RSA (Republic of South Africa). 1995b. Explanatory Memorandum Department of Labour, 2 February. Pretoria: Government Printer.

RSA (Republic of South Africa). 1996. Constitution of the Republic of South Africa. Pretoria : Government Printers.

Sterner, P. 1996. 'Workplace Forums - a new institution in South Africa: A comparison to the German Works Councils'. Unpublished masters thesis. Cape Town: University of Cape Town.

Visser, J. 1995. The Netherlands: From paternalism to representation. In Rogers, J. \& Streeck, W. (Eds.). Works Councils: Consultation, representation and cooperation in industrial relations. Chicago: Chicago University Press.

Van der Walt, R. v. M. 1997. Will Workplace Forums enhance industrial democracy in South African organisations? Annual EBM Research Conference of the NPI. Pretoria. Unpublished conference paper.

Van der Walt, R. v. M. 1998. 'What is happening with regard to Workplace Forums in South African organisations?’ People Dynamics, 16(6):25-39.

Wood, G. \& Mahabir, P. 2001. 'South Africa Workplace Forum system: A stillborn experiment in the democratisation of work', Industrial Relations Journal. 32(2):230-243. 